\title{
DAS CONTRIBUIÇÕES DA TEOLOGIA POLÍTICA DA REFORMA PROTESTANTE ÀS DECLARAÇÕES DE DIREITOS HUMANOS
}

Givaldo Mauro de Matos

\begin{abstract}
Resumo: O presente artigo analisa a proposição de que a Reforma Protestante representa um momento seminal do assentamento dos direitos individuais e, consequentemente, do espírito das declarações de direitos humanos modernos, tal como defendem os politólogos Georg Jellinek e Celso Lafer. A pesquisa se desdobra em aferir o reconhecimento filosófico da relação entre o Cristianismo e o conceito de dignidade humana, o aprofundamento deste conceito promovido pela Reforma Protestante e a contribuição específica deste movimento para a naturalização dos conceitos fundamentais que deram origem às declarações de direitos humanos dos séculos XVIII e seguintes.
\end{abstract}

Palavras-chave: Reforma Protestante; Direitos Humanos; Modernidade.

\section{THE CONTRIBUTIONS OF POLITICAL THEOLOGY OF PROTESTANT REFORM TO HUMAN RIGHTS DECLARATIONS}

\begin{abstract}
This article analyzes the proposition that the Protestant Reform represents a seminal moment in the establishment of individual rights and, consequently, the spirit of modern human rights declarations, as advocated by political scientists Georg Jellinek and Celso Lafer. The research unfolds to assess the philosophical recognition of the relationship between Christianity and the concept of human dignity, the deepening of this concept promoted by the Protestant Reform and the specific contribution of this movement to the naturalization of the fundamental concepts that gave rise to the human rights declarations of the eighteenth and following centuries.
\end{abstract}

Keywords: Protestant Reform; Human Rights; Modernity.

\section{DE LAS CONTRIBUCIONES DE LA TEOLOGÍA POLÍTICA DE LA REFORMA PROTESTANTE A LAS DECLARACIONES DE DERECHOS HUMANOS}

Resumen: El presente artículo analiza la proposición de que la Reforma Protestante representa un momento seminal del asentamiento de los derechos individuales $\mathrm{y}$, consecuentemente, del espíritu de las declaraciones de derechos humanos modernos, tal como defienden los politólogos Georg Jellinek y Celso Lafer. La investigación se desdobla en apreciar el reconocimiento filosófico de la relación entre el Cristianismo y el concepto de dignidad humana, la profundización de este concepto promovido por la Reforma Protestante y la contribución específica de este movimiento a la naturalización de los conceptos fundamentales que dieron origen a las declaraciones de derechos humanos siglos XVIII y siguientes.

Palabras Clave: Reforma Protestante, Derechos Humanos, Modernidad 


\section{CRISTIANISMO E DIREITOS HUMANOS - ESTABELECENDO RELAÇÕES}

O primeiro documento reivindicatório de direitos humanos - A Declaração de Independência Americana (1776), surge com notório tom de imperatividade. Thomas Jefferson, redator de seu texto original, assim a inicia: "Consideramos estas verdades evidentes por si mesmas, que todos os homens são criados iguais, que são dotados pelo Criador de certos direitos inalienáveis, entre os quais estão a vida, a liberdade e a busca de felicidade".

Na perspectiva de David Armitage (ARMITAGE, 2011, p.18), historiador da Universidade de Princeton, a declaração em epígrafe inaugura um novo gênero literário de escrita política, a saber, o das Declarações de Direitos, com poderes reais de fomentar ações revolucionárias ao redor do mundo, como acabou por acontecer. Estabeleceu-se como uma espécie de manifesto, acerca do qual se fundamentariam as pretensões das classes descontentes mundo afora, consistindo-se numa reivindicação de direitos fundada não mais no Estado, na Natureza ou em Deus, antes, na intrínseca dignidade humana. Inicia-se, assim, a moderna história dos direitos humanos.

Questão fundamental desta sentença inaugural da Declaração é estabelecer o "como e o quando" estes direitos inalienáveis alcançaram status de auto-evidência. Paul Johnson, historiador americano, sinaliza a dificuldade de se simplificar este problema: "Todas as grandes descobertas conceituais do intelecto parecem óbvias e inevitáveis uma vez tendo sido reveladas. Porém, isso requer um gênio especial para formulá-las pela primeira vez”, conclui (Apud ZVEITER, 2005, p.67).

A presente abordagem procura identificar elementos de contribuição da Reforma Protestante enquanto cultura germinativa da modernidade no Ocidente, à filosofia dos direitos humanos assinalados na Declaração Americana.

De imediato, observa-se relativa exiguidade de pesquisas. Segundo o jurista Guy Aurenche, "está por ser feito o estudo das relações entre o Cristianismo e o estabelecimento dos direitos humanos ao longo de dois mil anos decorridos" (RÉMOND, 2005, p. 189). Notase ainda certo descaso na direção desta pesquisa, sobretudo por causa da anticlerical filosofia iluminista, matriz da Revolução Francesa. Como observa o teólogo alemão Karl-Josef Kuschel, a contribuição das religiões monoteístas para a configuração teórica dos direitos humanos não é unanimemente reconhecida entre os estudiosos do tema. Em suas palavras, 
É um lugar comum afirmar que as declarações sobre direitos humanos universais não são um produto direto do judaísmo, cristianismo e islã, e sim uma conquista da modernidade que, em muitos aspectos, tem uma postura crítica para com a religião (KUSCHEL, 2007, p. 05).

Em direção inversa, para o jurista Fábio Konder Comparato, a contribuição religiosa não pode ser ignorada na historiografia da filosofia dos direitos humanos. Em sua leitura, "historicamente, a excelência do homem no mundo foi justificada a partir de três perspectivas, complementares e não excludentes: a religiosa, a filosófica e a científica" (2006, p. 481). Na mesma direção, os juristas Eduardo C. B. Bittar e Guilherme Assis de Almeida, na obra conjunta Curso de Filosofia do Direito, destacam a necessidade de metodologia multidisciplinar para analisar temas desta dimensão:

Falar sobre justiça é falar sobre um fenômeno multifacetado, o que justifica deparar-se com abordagens diversificadas, tantas quantas sejam as facetas do problema colocado em análise - faceta metafísica, faceta ética, faceta técnica, faceta religiosa (BITTAR \& ALMEIDA, 2005, p. 154-155).

Para Bittar e Almeida, no Ocidente, "as tradições, os hábitos, os costumes, as crenças populares, a moral, as instituições, a ética, as leis... estão profundamente marcadas pelas lições cristãs". Por essa razão, "quando se discute direito e justiça, é imprescindível analisar a influência que as Sagradas Escrituras produziram sobre a cultura ocidental" (BITTAR \& ALMEIDA, 2005, p. 145).

A influência dos movimentos religiosos do século XVI na Europa para os desdobramentos que irão culminar na filosofia dos direitos humanos não passou desapercebida pelo filósofo e historiador da filosofia francês, Luc Ferry. Em sua análise,

Apoiando-se numa definição da pessoa humana e numa forma de pensamento inédita acerca do amor, o Cristianismo vai deixar traços incomparáveis na história das ideias. Não os compreender é também impedir-se de aceder a qualquer compreensão do mundo intelectual e moral no qual ainda hoje vivemos. Para dar apenas um exemplo, é perfeitamente claro que, sem esta valorização tipicamente cristã da pessoa humana, do indivíduo enquanto tal, a filosofia dos direitos do homem, à qual estamos tão ligados hoje, nunca teria visto o dia (Apud LENOIR, p. 184).

Alguns termos de Ferry chamam a atenção: 'É perfeitamente claro que, sem esta valorização tipicamente cristã da pessoa humana (...) a filosofia dos direitos humanos (...) nunca teria visto o dia”. Esta clareza é questionável. No entanto, a perspectiva de Ferry se apresenta como desafio para a reanálise de em que medida o Cristianismo - mais especificamente, a teologia e as práticas dos movimentos interligados à Reforma Protestante 
- colaboraram para a elaboração teórica dos direitos humanos.

\title{
REFORMA PROTESTANTE E DIREITOS HUMANOS
}

Ao dissertar sobre a posição do indivíduo na relação com os poderes políticos, Norberto Bobbio esclarece que na Antiguidade, "o indivíduo singular é essencialmente um objeto do poder ou, no máximo, um sujeito passivo". Ainda, "mais do que de seus direitos, a tratadística política fala dos seus deveres, entre os quais ressalta, como principal, o de obedecer as leis" (1992, p. 58). Frente ao Estado, à religião, à família ou ao grupo social a que pertence, o indivíduo enquanto sujeito de direitos não existe.

Ora, esta é a grande ruptura provocada pela modernidade. Citando Michael Ignatieff, Emilio Garcia Mendez, da Universidade de Buenos Aires, situa aqui o contexto contra o qual surge a linguagem dos direitos humanos: "[Os] direitos humanos são a linguagem mediante a qual os indivíduos criaram uma defesa de sua autonomia contra a opressão da religião, do Estado, da família e do grupo" (2004, p. 10).

É neste sentido que o jurista Celso Lafer (A Reconstrução dos Direitos Humanos) assinala a contribuição da Reforma Protestante: é a primeira grande revolução na Europa a fazer frente ao Estado e à Igreja, na pretensão exercida até então de controle sobre as crenças individuais:

\begin{abstract}
A passagem das prerrogativas estamentais para os direitos dos homens encontra na Reforma, que assinala a presença do individualismo no campo da salvação, um momento importante da ruptura com uma concepção hierárquica de vida no plano religioso (...). Desta ruptura da unidade religiosa deriva o primeiro direito individual reivindicado: o da liberdade de opção religiosa (LAFER, 2008, p. 121).
\end{abstract}

A tese de que a liberdade de crença é um direito inalienável estabeleceu-se, portanto, como um instrumento político limitador das prerrogativas de instituições que se assentavam soberanas até então (o Estado, a Igreja e o grupo de pertença social). Assim expressa o teólogo Wolfgang Huber:

A Reforma expressou as ideias da não-disponibilidade do ser humano na sua doutrina da justificação, ou seja, ela substituiu as definições filosóficas tradicionais do homem pela 'definição' na qual o homem seria justificado pela crença. $\mathrm{O}$ fato de que não se poderia impor uma crença ao homem ou que ele não deveria ser coagido em sua consciência era, na verdade, uma consequência em si inevitável desta visão da crença cristã, não obstante na 
época pós-Reforma ela tenha sido frequentemente violada por todos os lados (HUBER, 1979, p. 11).

Para o historiador Ernst Troeltsch (1865-1923), “o protestantismo 'liberou o Estado de toda a subordinação à hierarquia e, embora não criasse a moderna concepção de Estado, preparou-lhe o caminho para tal” (Apud BIELEFELDT, 2008, p. 228). Nesta mesma linha, para Georg Jellinek, professor da Universidade de Heidelberg do início do século XX, é a Revolução Protestante que primeiro consagrará a inviolabilidade do indivíduo:

La idea de consagrar legislativamente esos derechos naturales, inalienables e inviolables del individuo, no es de origen politico, sino religioso. Lo que hasta aqui se ha recebido como uma obra de la Revolución, es em la realidade um fruto de la Reforma e de sus luchas. Su primer apóstolo no es Lafayette, sino aquel Roger Willians que, llevado de su entusiasmo religioso, emigraba hacia las soledades, para fundar un império sobre la base de liberdad de las creencias, y cuyo nombre los americanos aun hoy recuerdan con veneración (JELLINEK, 2000, p. 125).

$\mathrm{Na}$ esteira da obra do politólogo Kentin Skinner (As Fundações do Pensamento Político Moderno), Jellinek concentra sua atenção nos fermentos teóricos presentes no século $\mathrm{XVI}$, germinal das teorias constitucionalistas e limitadoras do poder estatal e religioso. Por esta razão é que o século XVI é reconhecido pelo politólogo como tendo sido o 'primero siglo de la história moderna' (JELLINEK, 2000, p. 312).

A radicalidade das ideias de Jellinek, de que as lutas dos revolucionários protestantes precederam a influência dos movimentos políticos do século posterior no assentamento dos direitos individuais, não foram acolhidas de forma unânime entre estudiosos do tema. Sobre esta discussão, o teólogo Wolfgang Huber, pronunciara-se:

Esta tese não se sustentou devido à sua unilateralidade. É verdade que não se pode pensar no progresso dos direitos humanos sem os movimentos religiosos que os precederam. Porém, a ideia da liberdade de consciência não é de forma nenhuma a razão básica única, nem mesmo a predominante dos direitos humanos (APUD CONCILIUM, 1979, p. 11).

Apesar de não compartilhar da perspectiva unilateral de Jellinek, Huber recalca a tese de que o movimento reformador ocupa lugar distintivo no estabelecimento da liberdade de consciência, derivando daí a conclusão da importância deste movimento na limitação do poder estatal sobre o indivíduo: "Através da exigência de liberdade de consciência e liberdade de culto, declara-se a convicção de que nenhum poder estatal ou social tem o direito de definir seres humanos ou dispor de sua existência” (APUD CONCILIUM, 1979, p. 
$11)$.

Do assentamento desta inviolabilidade (de consciência), os protestantes do Séc. XVI irão derivar radicais concepções políticas, que por sua vez provocarão profundas rupturas na estrutura do mundo medieval.

\section{A TEOLOGIA POLÍTICA DA REFORMA PROTESTANTE DO SÉCULO XVI}

Iniciada com a publicação das Noventa e Cinco Teses de Martinho Lutero, na porta da igreja do castelo de Wittenberg, em 31 de outubro de 1517, o luteranismo, ao lado do calvinismo, marcou uma das duas maiores faces da Reforma. Quentin Skinner, em sua clássica obra As Fundações do Pensamento Político Moderno, faz uma linha cronológica e espacial que demonstra como em pouco tempo as doutrinas sociais e políticas oriundas da teologia de Lutero avançou em aceitação na Europa do Norte (SKINNER, 2006, p. 302).

Já nos primeiros anos, a Reforma marchou conquistando a Saxônia, a Prússia, Homberg, Brunswick, Schleswig, Mansfeld, Brandenburgo-Pomerânia e Württembert. Em 1534, os luteranos controlavam Altenburgo, Bremen, Erfurt, Gotha, Magdeburgo, Nurembert, Augsburgo, Frankfurt, Hanover, Estraburgo e Ulm.

Depois da Alemanha, deixou raízes na Escandinávia, na Dinamarca, na Islândia, Noruega e Suécia. Após, vieram a Escócia e a Inglaterra, em meados de 1540. Em alguns casos, a conversão se deu pela adesão popular às teses teológicas de Lutero. Em outros casos, a adesão iniciou-se com o príncipe, que declarava seu apoio público e político à Reforma, levando assim, o povo de seu domínio, à profissão da fé luterana.

Na medida em que avançava, a Reforma culminava em um repúdio à jurisdição política e jurídica católico-romana, na apropriação dos bens eclesiásticos pelas autoridades seculares e em uma grave repressão a quem contrariasse os ideais do movimento reformador (SKINNER, 2006, p. 373). Isto porque a teologia reformada atacava não apenas o tráfico que a Igreja exercia sobre as indulgências, mas também todo o conjunto de atitudes sociais, políticas e religiosas da Igreja Católica que fundamentavam seu domínio.

Para Skinner, a teologia de Lutero trazia consigo implicações políticas da maior importância, que, somadas, respondem pelo que é mais distintivo e influente em seu pensamento social e político: o individualismo, a dissolução do lugar hegemônico que a Igreja Católica Romana ocupava na Europa medieval e a separação entre os poderes eclesiásticos e seculares. 
A teologia política de Lutero que provocará tais eventos se encontram, pela primeira vez, desenvolvidas no seu Manifesto de 1520, dirigido à 'nobreza cristã da nação germânica'. Em primeiro lugar, Lutero desqualificará a importância da Igreja enquanto instituição visível, para mediar a relação entre os fieis e a divindade. De acordo com seu pensamento, a fé é o único requisito para dar ao indivíduo o desfrute da salvação (Sola fides). Nasce aqui uma indisposição contra qualquer tentativa de controle do pensamento. Neste sentido, a prerrogativa de exercer um sacerdócio especial, da Igreja Católica, sofreria um duro golpe nos países protestantes. A partir de então, Lutero sustentará que a Igreja é simplesmente congregratio fidelium, ou seja, "uma congregação dos fiéis em nome de Deus" (SKINNER, 2006, p. 292-93).

Em segundo lugar, Lutero rejeitará a ideia segunda a qual a Igreja possui poderes de jurisdição, e por isso detém autoridade para dirigir e regular a vida cristã. Essa regulação da vida cristã podia ser vista no tráfico de indulgências que neste período se fazia, motivo que levou Lutero a expressar sua indignação inicial, nas Noventa e Cinco Teses fixadas na porta da Igreja de Wittemberg (SKINNER, 2006, p. 294).

O verdadeiro alvo dos ataques de Lutero, contudo, não foi tanto o fato da Igreja abusar de seus poderes - mas a sua mera pretensão a exercê-los sobre uma sociedade cristã. Foi isso o que o levou a denunciar todas as instituições da Igreja que estivessem fundadas na tese segundo a qual o clero constitui uma classe distinta, com jurisdições e privilégios específicos. Por isso, uma de suas propostas é que 'seria muito bom que todo o direito canônico fosse revogado por inteiro', já que 'a maior parte dele a nada recende, a não ser arrogância e ganancia', enquanto a autoridade absoluta do papa sobre a interpretação de seu conteúdo torna qualquer estudo rigoroso do mesmo 'mera farsa e perda de tempo' (SKINNER, 2006, p. 295).

Em sua visão, se a igreja não passa de uma congregatio fidelium, deve reservar-se a esta tarefa, enquanto as autoridades seculares devem exercer exclusivamente todos os poderes coercitivos, inclusive sobre a própria igreja. Ainda,

Sendo o poder temporal ordenado por Deus, a fim de punir os maus e proteger os bons, deve ter a liberdade de cumprir seu ofício no corpo inteiro da cristandade sem restrição e sem acepção de pessoas, pouco importando que afete o papa, os bispos, padres, freiras ou quem quer que seja (SKINNER, 2006, p. 297).

Sendo assim, "a ideia do papa e do imperador com poderes paralelos e universais 
desaparece, e as jurisdições independentes do sacerdotium são confiadas às autoridades seculares" (SKINNER, 2006, p. 297). Há que se guardar uma separação clara no exercício de prerrogativas e poderes.

Reconhecendo que o Regime Antigo funda-se na tese das hierarquias naturais, o conceito oposto de Lutero, do 'sacerdócio universal', ou seja, da desnecessidade de mediação entre os fiéis e qualquer instituição humana na direção do sagrado, representará uma das raízes do conceito de igualdade e liberdade laica moderna. Além de provocar definitiva ruptura entre as ideias medievais de submissão do ser humano às instituições que se estabeleceram como tutoras de sua mente e alma, o movimento luterano conquistou outra radical vitória sobre o que posteriormente viria a contribuir decisivamente para a elaboração dos direitos humanos: a separação entre Igreja e Estado. Daí o jurista Antônio Carlos Wolkmer considerar de importância fundamental a contribuição da Reforma à filosofia dos direitos humanos:

Inegavelmente, toda a problemática própria do mundo moderno e da filosofia dos direitos fundamentais não teria sido possível sem este passo prévio, sem esta secularização do Estado e do Direito, no que foi essencial a contribuição da Reforma Protestante (WOKMER, 2005).

Neste sentido, Georg Jellinek já havia se pronunciado: "La polémica entre el Estado y la Iglesia se decide en benefício del Estado, por obra de la Reforma" (JELLINEK, 2000, p. 312). É o início do que, em termos políticos, materiais e concretos, virá a ser chamado 'modernidade'. Nunca mais a Igreja recuperará a posição que ocupara até então na Europa, tendo seu poder sido entregue à sociedade laica.

\section{RAÍZES DO CONSTITUCIONALISMO NOS MOVIMENTOS DA REFORMA}

Conflito não menos importante para a identificação da contribuição da Reforma para a elaboração das declarações de direitos encontra-se nos debates acerca da legitimidade de confrontação às autoridades civis, quando estas usurparem de suas funções. Até que ponto é devida a obediência a uma autoridade tirânica?

Nos primeiros anos da Reforma, a teologia de Lutero sobre a relação entre os súditos e os magistrados se mostrou conservadora. Primando mais pela ordem do que pela revolução social, contentava-se em repetir a fórmula destacada no texto bíblico paulino que 
se encontra na Carta aos Romanos [Cap. 13:1-4] (BÍBLIA, 1991), sem se preocupar com possibilidade de diferente interpretação. Nesta pode se ler:

Toda a alma esteja sujeita às potestades superiores; porque não há potestade que não venha de Deus; e as potestades que há foram ordenadas por Deus. Por isso quem resiste à potestade resiste à ordenação de Deus; e os que resistem trarão sobre si mesmos a condenação. Porque os magistrados não são terror para as boas obras, mas para as más. Queres tu, pois, não temer a potestade? Faze o bem, e terás louvor dela. Porque ela é ministro de Deus para teu bem. Mas, se fizeres o mal, teme, pois não traz debalde a espada; porque é ministro de Deus, e vingador para castigar o que faz o mal.

Seguindo o texto paulino, Lutero afirmará que todas as autoridades seculares são estabelecidas pela divindade, implicando em que seus decretos devem ser, por esta razão, respeitados. Ante a questão de uma ordem absurda - ou contrária à fé - Lutero, no início da Reforma, teria resguardado apenas o direito de livre consciência, mas afirma que a resistência, nestes casos, deve ser a atitude de submissão e não a revolta. "Não se obedece a ordem má, mas se submete ao castigo que possa advir de tal obediência", pondera o reformador. Ainda:

Não é de modo algum apropriado a quem quer que pretenda ser cristão oporse à autoridade de seu governo, não importando se o governo age certo ou errado, (...) porque, mesmo que aja mal, este fato não abole a autoridade do governo imperial (APUD SKINNER, 2006, p. 472).

A princípio, a limitação ao poder se deu, portanto, apenas de forma genérica, deixando em lacuna o debate sobre a revolução ou guerra civil contra a tirania. Lutero fora contrário, por exemplo, à Revolta dos Camponeses (1524-1526), apoiada, por sua vez, pelo seu ex-discípulo Thomas Münzer, contra os privilégios exercidos pela nobreza alemã, em detrimento da população campesina. Esta oposição de Lutero levou Münzer a chamá-lo de "doutor mentiroso e vida mansa", incapaz de levar a sério as implicações últimas de sua doutrina (VIEIRA, 2002).

De fato, a doutrina de Lutero trazia consigo implicações que fugiriam de seu controle. Décadas mais tarde, por exemplo, os movimentos sucessores da reforma passaram a defender algo radicalmente diferente:

Os fieis não serão condenados à danação eterna se resistirem às autoridades, constituídas, mas, pelo contrário, que serão condenados se não o fizerem, pois isto equivaleria a transgredir o 'pacto e aliança' que, nas palavras de John Knox, firmaram com o próprio Deus (SKINNER, 2006, p. 512). 
Ora, é em John Knox que se encontrará algumas das raízes da teoria constitucionalista da resistência, posteriormente adotadas pelas revoluções civis, primeira inglesa, depois americana e francesa. De onde estes radicais [movimentos religiosos], sobretudo os puritanos ingleses, retiraram tal fonte de resistência?

Em primeiro lugar, foi nas últimas teses do próprio Lutero, onde este fez algumas concessões ambíguas sobre o direito de resistência. Lutero teria afirmado na década de 1530 que se o imperador tivesse, por meio de lei, restringido sua própria autoridade, na medida em que ultrapassasse posteriormente esta restrição, poderia ser resistido, pois estaria usurpando sua própria autoridade outrora restringida (SKINNER, 2006, p. 476-77).

Ainda, em sua obra Da Autoridade Temporal, depois de firmar o dever de sujeição às autoridades no texto paulino [Romanos 13] Lutero enfrentará a questão da imposição que alguma autoridade poderia fazer a um súdito, de contrariar a vontade de Deus. Neste caso, afirma o reformador, “deve-se obedecer a Deus antes que aos homens". E continua: "De fato, se acaso se devesse obedecer a tudo o que o poder temporal quer, essas palavras 'deve-se obedecer antes a Deus que aos homens' teriam sido em vão" (LUTERO, 2010, p. 106). O debate sobre o que deveria estar compreendido na expressão 'vontade de Deus' virá a consistir na brecha necessária para que outros reformadores estendam as possibilidades de resistência legítima.

Em seus últimos dias, também Calvino abrirá duas exceções ao dever de obediência aos magistrados. A primeira, ao afirmar em um comentário sobre o livro de Atos dos Apóstolos que "se um rei, príncipe ou magistrado se conduz de modo a diminuir a honra e o direito de Deus, converte-se em nada mais do que em um homem comum", passível de resistência (Apud. SKINNER, 2006, p 494).

Em segundo lugar, na última parte das suas Institutas da Religião Cristã procederá sua principal abertura, adotada por seus sucessores revolucionários, que desenvolverão, a partir de então, a teoria de resistência aos tiranos, visualizadas, sobretudo nos monarcômacos do século XVII. Na seção 31 do Livro IV das Institutas, se lerá:

Porque si ahora hubiese autoridades ordenadas particularmente para defensa del Pueblo y para refrenar la excessiva licencia que los reyes se toman, como antiguamente los lacedemônios tenían a los éforos opuestos a los reyes, y los romanos a los tribunos del Pueblo frente a los cônsules, y los atenienses a los demarcas frente al senado, y como puede suceder actualmente que en cualquier reino lo sean los tres estados cuando se celebran cortes; tan lejos estoy de prohibir a tales estados oponorse y resistir, conforme al oficio que tienen, a la excessiva licencia de los reyes 
(CALVINO, 1999, p. 1193).

Sobre estas notas de Calvino se fundamentarão as teorias de dois tipos de autoridades, uma refreando o poder da outra. Será legítima a resistência às autoridades, se estas foram realizadas por outras autoridades, eleitas para fiscalizarem o exercício do poder da primeira. Não faltarão grupos que se autoconstituirão em 'autoridades fiscalizadoras', com interesse de enfrentar a monarquia, como se verá no século XVII, na Inglaterra.

Por fim, na seção 32 do mesmo livro das Institutas, continuará limitando o dever de obediência ao soberano, afirma:

Si ellos mandan alguna cosa contra lo que Él há ordenado no debemos hacer ningún caso de ella, sea quien fuere el que lo mande”. Não há injúria alguma nesta desobediência ao superior, acrescenta o reformador, pois "por más alto que sea, cuando lo sometemos y ponemos bajo la potencia de Dios, que es la sola y verdadeira potencia em comparación com las otras (CALVINO, 1999, p. 1194).

Abrir-se-á aqui espaço para constantes discussões sobre o que deva ser interpretado como 'ordenanças contrárias à vontade divina'. Em última instância, Calvino, ao não ser preciso em suas orientações, abre espaço para incontroláveis interpretações, característica do movimento reformado radical chamado de puritanos.

Estas foram as brechas necessárias para os movimentos da reforma relerem a teologia da obediência. Com o crescimento das perseguições na Europa, sobretudo depois do trágico evento da Noite de São Bartolomeu na França, os teólogos luteranos e calvinistas passaram a enfrentar o tema com maior plasticidade, desenvolvendo justificativas teológicas para o enfrentamento do poder político.

O espaço dado por Lutero à resistência aos tiranos, foi desenvolvida com maior clareza por Melanchthon, teólogo adepto do luteranismo: "Se o magistrado atormenta seus súditos com injúrias atrozes e notórias, é legal que eles se defendam, de um modo adequado à república, tal como o fariam no caso de um perigo privado" (APUD SKINNER, 2006, p. 478).

Desenvolvendo sua tese, usa o argumento do instinto natural implantado pela divindade no ser humano, a fim de o levar à autopreservação. É este instinto, que leva o ser humano a repelir a injustiça e a violência desmedida. "Se o magistrado falha em seu cargo ou passa a agir criminosamente, será lícito repelir essa força injusta com qualquer ajuda que se possa obter, ou mesmo com as próprias mãos”, conclui o reformador.

Em linha sucessória, outro teólogo luterano [tributário de Calvino, neste conceito] a 
desenvolver a tese da resistência legítima foi Andreas Osiander. Seu conceito de resistência, inspirará as teorias constitucionais de limitação dos poderes do príncipe. Para Osiander, as autoridades a quem o apóstolo Paulo afirma (na Carta aos Romanos, capítulo 13) terem sido instituído por Deus devem ser vistas em duas divisões: a dos magistrados superiores [os reis] e a das autoridades inferiores, que eram os príncipes territoriais e um conjunto de autoridades locais. Cada uma destas autoridades desempenha função específica. Sendo assim,

Se um magistrado superior deixar de desempenhar os deveres para os quais foi ordenado, seus magistrados inferiores, que 'são tanto quanto eles ordenados por Deus', podem legitimamente resistir-lhe, para assegurar que a suprema necessidade de um governo bom e piedoso seja invariavelmente atendida (SKINNER, 2006, p. 480).

A partir da mesma plataforma bíblica, Osiander cria uma forma de confrontação das autoridades, a saber, a partir das próprias autoridades inferiores. Estas passam a desempenhar um papel de equilíbrio e de juízo do poder, importante para revoluções que ocorrerão no século vindouro.

Com entendimento semelhante a Osiander, apresenta-se a teoria do teólogo Martin Bucer, publicada ainda em 1527. Para Bucer, Deus não transferiu todo o poder de governo para uma única pessoa. $\mathrm{O}$ debate sobre a submissão à autoridade imposta por Deus seguirá, portanto, não mais à questão de se há o dever de obediência, mas que tipo de obediência se deve a uma autoridade que viola a função para a qual foi instituída e quem tem legitimidade para resistir. As autoridades inferiores, conclui Bucer, tendo jurado a defesa dos inocentes, deveriam cumprir a função para a qual Deus os instituiu, resistindo as ações de autoridades superiores, se estas contradizem a função para a qual foram instituídas [por Deus]. Acrescenta:

$\mathrm{Na}$ verdade, têm o inegável dever, que não pode ser negligenciado, de garantir que, se uma autoridade superior começa a praticar a extorsão ou causar qualquer outro tipo de injúria externa, ela seja deposta por força das armas (SKINNER, 2006, p. 481).

A teoria de Bucer foi, em abril de 1550, ampliada em um documento chamado Confissão e Apologia dos Pastores e outros Ministros da Igreja em Magdeburgo. Este documento foi escrito por ocasião de conflito experimentado pela cidade de Magdeburgo, contra o Império, escrito por Nicolas von Amsdorf, junto com mais oito dos mais importantes 
ministros luteranos da época. No documento, gravou-se como tese fundamental a seguinte ideia:

Toda vez que um magistrado superior perseguir seus súditos, o magistrado inferior, pela lei da natureza, pela lei divina e pela verdadeira religião e reverência a Deus, deve, por ordem de Deus mesmo, resistir-lhe (SKINNER, 2006, p. 483).

As hierarquias são relativizadas a partir de autoridades popularmente criadas. Segundo Skinner, o documento passou a ser o principal instituto de defesa dos movimentos da reforma contra governos tirânicos, sendo adotados, posteriormente, pelos calvinistas.

Em 1556, após eclodir a guerra de Schmalkalden, sofreu um grande e importante acréscimo de interpretação: o direito de resistência estendeu-se ao direito privado. Seguindo as linhas do que já havia até então, reiterava-se que 'o magistrado foi instituído por Deus para a honra das boas obras e o terror para as más'. Neste sentido, defenderam que "se o magistrado passar a ser um terror para as boas obras e uma honra para as más, então não pode mais ser considerado uma autoridade instituída por Deus" (Cf. (SKINNER, 2006, p. 492).

Isso implicaria em que sempre que um governante excedesse os limites de seu cargo, deixaria de ser um genuíno magistrado, situação em que a resistência não mais representaria desobediência a Deus. A resistência, no entanto, a este tipo de ilegitimidade das autoridades, deveria passar pelas fórmulas já contidas na Confissão, a saber, "quem quer que vá resistir, é essencial que resista de acordo com seu lugar e em razão de sua função" (SKINNER, 2006, p. 495), livrando de que o presente entendimento associado ao direito privado desembocasse em legitimação de insurgências anárquicas no âmbito privado, sempre que um civil se sentisse lesado pelas autoridades.

Nestes termos, a teologia radical da Reforma permitiria a relativização de um dos mais importantes fundamentos do poder na antiguidade, a saber, a ideia de que todo poder, porque oriundo de Deus, deveria ser respeitado em absoluto. Para os puritanos, ao contrário, "era permitido desafiar o rei da Inglaterra quando se estava obedecendo as ordens do Rei dos Reis" (HILL, 1992, p. 12). Ordens estas que caiam num plano infinito de subjetividade, impedindo que a Igreja voltasse a, sob este fundamento, se estabelecer como mediadora entre Deus, as classes populares e os poderes estatais. A doutrina do livre sacerdócio fizera sua revolução.

Segundo a historiadora Karen Armstrong, foram estas ideias políticas calvinistas que Fronteiras: Revista de História | Dourados, MS | v. 19 | n. 34 | p. 94 - 109 | Jul. / Dez. 2017 
“inspiraram a Revolução Puritana na Inglaterra sob Oliver Cromwell, em 1645, e a colonização da Nova Inglaterra, na década de 1620" (ARMSTRONG, 2006, p. 282). De igual forma, o historiador Christopher Hill, em sua obra As Origens Intelectuais da Revolução Inglesa, vaticinará que "as ideias que mobilizaram os homens para a Revolução [Inglesa] vieram principalmente dos puritanos, com o conveniente apoio dos cientistas" (HILL, 1992, p. 08). Na interpretação de Skinner, "a teoria da revolução popular desenvolvida pelos calvinistas radicais, na década de 1550 , estava destinada a dar início àquela que seria a corrente dominante no pensamento constitucionalista moderno" (SKINNER, 2006, p. 513).

A partir das teologias políticas originadas por ocasião da Reforma Protestante, o mundo jamais voltaria a ser como dantes.

\section{CONSIDERAÇÕES FINAIS}

Em sua A Era dos Direitos, Norberto Bobbio expressa sua expectativa em relação aos mecanismos a serem desenvolvidos para a efetivação dos direitos humanos. Para o mestre de Turim, o caminho iria além de soluções de ordem filosófica, jurídica ou moral. Trata-se de "um problema cuja solução depende de certo desenvolvimento da sociedade e, como tal, desafia até mesmo a Constituição mais evoluída e põe em crise até mesmo o mais perfeito mecanismo de garantia jurídica" (BOBBIO, 1992, p. 45). Tem a ver, portanto, com o desenvolvimento global da civilização humana.

Em concepção análoga, a historiadora Lynn Hunt, em pesquisa sobre que condições teriam possibilitado à América do Norte e à França revolucionária erigir as primeiras declarações de direitos, concluiu que para a efetivação destes direitos, é necessário mais do que a consciência racional de suas existências. É preciso que eles sejam tomados como evidentes e necessários na dimensão emocional dos seres humanos. Há que se despertar a sensibilidade para tanto (HUNT, 2009, p. 19).

Esta sensibilização, como demonstrou a pesquisa, passa tanto pela fundamentação como pela inculturação de valores. Fundamentar, neste sentido, significa revelar a necessidade de algo, como fruto decorrente de uma determinada situação. Não se trata, portanto, de "encontrar o fundamento absoluto - empreendimento sublime, porém desesperado -, mas de buscar, em cada caso concreto, os vários fundamentos possíveis”, adverte Norberto Bobbio (1992, p. 24).

Neste sentido, mostra-se indubitável a preciosa contribuição que a Reforma 
Protestante ofereceu à cadeia histórica de fomento do espírito dos direitos humanos expressos nas declarações reivindicatórias do século XVIII e seguintes. No interim das grandes revoluções constitucionalistas europeias e americana, a Reforma esteve a amadurecer seus frutos, que continuariam nos séculos vindouros pondo o mundo de pontacabeça (Hill).

Por ocasião das comemorações no Brasil, dos 500 anos da Reforma Protestante, é imperativo destacar aos movimentos reformados seu princípio basilar: a luta pela liberdade de consciência, que faz do pluralismo de convicções e crenças seu fruto mais natural. Como destaca o sociólogo Valdinei Ferreira, sem esta lembrança, não seria exagero reconhecer que "o protestantismo corre o risco de repetir os mesmos erros cometidos pelo Cristianismo no período medieval", tempos em que a liberdade de consciência era uma heresia mortal (Apud CASTRO, 2017).

\section{REFERÊNCIAS BIBLIOGRÁFICAS}

ARMITAGE, David. Declaração de Independência - uma história geral. São Paulo: Companhia das Letras, 2011.

ARMSTRONG, Karen. Uma História de Deus - quatro milênios de busca do Judaísmo, Cristianismo e Islamismo. São Paulo: Companhia das Letras Editora, 2002. $6^{\circ}$ Ed.

Bíblia. Versão Revisada da Tradução de João Ferreira de Almeida. $3^{\circ}$ Impressão. Rio de Janeiro: Imprensa Bíblia Brasileira, 1991.

BIELEFELDT, Heiner. Filosofia dos Direitos Humanos. São Leopoldo: UNISINOS Editora, 2000.

BITTAR, Eduardo C. B. \& ALMEIDA, Guilherme A. Curso de Filosofia do Direito. São Paulo: Editora Atlas, 2005. $4^{\circ}$ Ed.

BOBBIO, Norberto. A Era dos Direitos. Rio de Janeiro: Editora Campus, 1992.

CALVINO, Juan. Institución de la Religión Cristiana. Barcelona: Fundación Editorial de Literatura Reformada, 1999.

CASTRO, C. G. Roberto. Lutero Promoveu o pluralismo moderno, diz pastor e sociólogo. JORNAL DA USP. http://jornal.usp.br/cultura/lutero-promoveu-o-pluralismo-moderno-dizpastor-e-sociologo/ >. Acesso em 16/01/2018.

COMPARATO, Fábio Konder. Ética. São Paulo: Companhia das Letras, 2006.

CONCILIUM - Revista Internacional de Teologia. Igreja e Direitos Humanos - Direitos humanos: direito dos pobres? Petrópolis: Vozes, v. 144, n. 4, 1979.

HILL, Christopher. Origens Intelectuais da Revolução Inglesa. São Paulo: Martins Fontes Editora, 1992.

HUNT, Lynn. A Invenção dos Direitos Humanos - uma história. São Paulo: Companhia 
das Letras, 2009.

JELLINEK, Georg. La Declaración de los Derechos del Hombre y del Ciudadano. Mexico: Universidad Nacional Autónoma de Mexico: 2000.

JELLINEK, Georg. Teoría General del Estado. México: Fondo de Cultura Económica, 2000 .

KUSCHEL, Karl-Josef. Fundamentação Atual dos Direitos Humanos entre judeus, Cristãos e Muçulmanos. Cadernos Teologia Pública. Ano IV - N. 28 - 2007. São Leopoldo: Unisinos, 2007.

LAFER, Celso. A Reconstrução dos Direitos Humanos. São Paulo: Companhia das Letras, 2008 .

LENOIR, Frédéric. Cristo Filósofo. Portugal: Caleidoscópio Editora, 2008.

LUTERO, Martinho. A Liberdade do Cristão. São Paulo: Escala Editora, 2010.

MENDEZ, Emilio Garcia. Origem, Sentido e Futuro dos Direitos Humanos: Reflexões para uma Nova Agenda. SUR - Revista Internacional de Direitos Humanos. Vol.1 no.1 São Paulo 2004,

RÉMOND, René (Org). As Grandes Descobertas do Cristianismo. São Paulo: Editora Loyola, 2005.

SKINNER, Quentin. As Fundações do Pensamento Político Moderno. São Paulo: Companhia das Letras, 2006. 5. Reimpressão.

WOLKMER, Antônio Carlos. Humanismo Renascentista e Reforma Protestante. Periódicos UFSC. Revista Sequência. N. 50. Pg. 21-22. Julho de 2005. Disponível em < http://www.periodicos.ufsc.br/index.php/sequencia/article/view/15182 >. Acessado em 23 de julho de 2017.

ZVEITER, Waldemar. A Gênese Judaica dos Direitos Humanos. Rio de Janeiro: Topbooks Editora, 2005. 